\title{
The Effect Of Scientific Approach Toward The Increasing Mastery Of The Basic Natural Sciences Material To Students Of Madrasah Ibtidaiyah Teacher Education At Iain Bone
}

\author{
Suriani Nur ${ }^{1}$ \\ \{surianinur@iain-bone.ac.id\} \\ Pendidikan Guru Madrasah Ibtidaiyah IAIN Bone, Sulawesi, Indonesia.
}

\begin{abstract}
The Effect of Scientific Approach toward the Increasing Mastery of the Basic Natural Sciences Material to Students of Madrasah Ibtidaiyah Teacher Education at IAIN Bone. IAD has been taught to use conventional style by a one-way system such as the ecpository learning method. In order to mastery of IAD material is more increasing. So, it is important to look for the alternative of learning approaches for the students of PGMI IAIN Bone. This study aims to describe the influence of the scientific approach toward the increasing mastery of the Basic Natural Sciences material to Students of Madrasah Ibtidaiyah Teacher Education at IAIN BONE. The type of this research is quantitative research with the research design of Pre-Experimental by using One-Group PretestPosttest Design. The population of this research was all students of PGMI IAIN Bone and the sample was 28 people. The research instrument used the observation guide and test questions with data collection techniques to observe \& carry out tests. The result of students test were done the Wilcoxon test. Statistically, the significant of the confidence level $\alpha=0.05$ with the value of Asymp.Sig. (2-tiled) $=0,000<\alpha=0.05$, so it was concluded that there was the increasing mastery of the basic natural science learning material (IAD ) through the scientific approach to students of Madrasah Ibtidaiyah Teacher Education at IAIN Bone
\end{abstract}

Keywords: Scientific approach, Basic Natural Sciences

\section{Introduction}

The $21^{\text {st }}$ century is a digital era and to enter the era of the 4.0 industrial revolution, a century offers much hope for ease in living life. The humans experience a paradigm shift and lifestyle due to the rapid development of science and technology. They can not resist the change that occur today, but they must respond with all the intelligence that they have. Sustainable innovation in the igital Era is the right step for the development of science and so as not to be left behind and run over by the rapid change of life. Khun (in Hergenhahn) commented that science will experience the innovation if scientists find a new phenomenon to show the alternative paradigm so that science and science change through a series of scientific revolutions Hergenhahn (2010: 26) and to educate qualified humans. The world of education is one of the means by which human beings are formed, and therefore it must improve, if they want to produce excellent and qualified human.

Indonesia as one of the part of the global world community has responded to the challenges of the $21^{\text {st }}$ century, the digital era and the 4.0 industrial revolution in the field of education by giving birth to the 2013 curriculum. The 2013 curriculum revision did to adjust 
life changes through the management and the regulation of national education standard, especially, it concern the standard of graduate competence, the content standard, the process standard and the education assessment standard. Mulyasa (2018: 19) states that the orientation toward the education standard must be broadened to make it easy and to make various changes that face the challenge of the future industrial revolution. Particularly it relates the change of the knowledge map, the acceleration of science and technology, the economic power, the modern social culture, and the post modern era that demand various changes of education.

The Law of the Republic of Indonesia Number 20 Year 2003 is about the National Education System states that education is a conscious and planned effort to create an atmosphere of learning and learning process so that the students is active to develop their potential to have religious spiritual strength, self-control, personality, intelligence, noble character, as well as the skills need by himself, the national community and the National Education Destination State are to educate the nation's life and develop Indonesian people as a whole, namely humans who have faith and devotion to God Almighty and virtuous character, have knowledge and skills, physical health and spiritual, steady and independent personality and sense of community and national responsibility. (Law on National Education System Number 20 Year 2003).

To observe the definition of education according to the National Education System Law, it can be seen the education is an activity that deliberate to designed in a planned manner by the state so that Indonesian people can develop their potential and then they have power. Because only strong humans in the broadest sense are able to live the $21^{\text {st }}$ century, the industrial revolution 4.0 and the digital era. The education has the national goal with a tough task in forming excellent and qualified human, people who have high intellect but do not forget the creator through faith and devotion and they have a sense of the national love. In line with Marzuki (2015: 3), states the national education excetus a mission, to build a complete and complete human who has great character values as well as having a strong foundation of faith and piety. Therefore, the education becomes an agent of change that it can improve the character of the nation (Marzuki, 2015: 3).

The national education has a lot of homework to be addressed in order to realize the quality and competitive national people at the local, regional and international level. One thing that needs attention is the learning approach still too dominated by the teacher's role (teacher centered) which places the students as objects. There are still many schools and madrassah through the role of the teachers lacking the opportunity for the students in a variety of subjects, to develop the ability to think holistically (thoroughly), critical, creative, objective and reasoning. The revised 2013 curriculum implementation is expected in 2020/2021, all levels of primary and secondary education are already to use it. The spearhead of the 2013 curriculum implementation is in this case, there are still the teachers who have not been able to realize learning with the students as the center of learning. One of the reasons for the teachers is the lack of knowledge about how to conduct learning as expected in the 2013 curriculum. So it is important to introduce a learning approach that it is in accordance with the mandate and regulations contained in the latest curriculum, at the level of the students of PGMI as the candidate of madrasah ibtidaiyah teachers include to introduce the scientific approach.

The scientific approach is a learning process to designed so that the students are active to construct the concepts, the laws or the principles through the stages of observing (to identify or find problems), the formulate problems, the propose or the formulate hypotheses, the collecting data with various techniques, to analyze data, to draw the conclusions and to communicate the concepts, the laws or the principles found. The scientific approach is intended to provide the understanding to the students in knowing, the understanding various 
materials using a scientific approach, that the information can come from various sources and does not make the teacher as the only source. The consequences of the digital age with information is spreading rapidly into learning spaces and classes wherever they are.

The scientific learning is as an application of the science process skills, it is the important thing to do to consider the rapid development of science and technology to make it impossible for teachers as the only sources and people who the channel facts, the theories and the concepts. So it is necessary to develop skills and experience in students as well as to optimize the learning outcomes. The cultivating of attitude is to love science and as the seeker of the true rightness and the systematic introduction of the seeking of the rightness through the scientific methods that it will direct students to the awareness of the human limitations and the excellence compared to the knowledge and the technology (Tawil, 2014: 10)

This research is important to be appointed because the approach taken by some IAD lecturers, so far it still uses the conventional style with the one-way system such as the lecture method. Therefore, the mastery of IAD material more increased, it is important to find the alternative learning approaches for the students of PGMI IAIN Bone. The selection of the scientific approach is in teaching IAD to the students of PGMI, furthermore it guide the students to think scientifically, it also teach to the candidate of Madrasah ibtidaiyah teachers how to solve problems scientifically, especially related to learning and life matters. Furthermore, the scientific approach is the approach to use in the current MI curriculum, it is the 2013 curriculum so that the candidate of MI teachers can recognize this approach.

IAIN Bone as one of the Educational Institutions and Educators (LPTK) at the State Islamic Religious College (PTKIN) is a produce of professional teachers and qualified people for future generations, who are experts in their fields. In addition to expert in their fields, the students of IAIN Bone, especially PGMI, it also must have the broad insight about the current issues, it includes those related to the natural sciences and the use of scientific approaches. The basic natural science is learned so that the students know the basic of natural science. Then they are more respect for nature and take good care of it, to utilize natural resources wisely and sensibly and to have the natural and scientific knowledge with the scientific approach.

\section{Method}

This type of research was based on the method called quantitative research with research design Pre-Experimental Design to use the type of One-Group Pretest-Posttest Design. The learning used a scientific approach to improve the mastery of IAD course material with a subtopic entitled "The Earth and Its Layers". The study population was all students of PGMI IAIN Bone and the sample was semester 1 students (group 1) for the experiment of 28 people, because this group was studying IAD courses in the current semester.

The data collection techniques of this research were to observe and conduct tests. Test did to determine the students' mastery of the material, test were conducted twice, namely pretest and posttest. The giving of pretest questions did before giving treatment to find out the students 'initial ability, while giving posttest questions did at the end of learning to find out students' abilities after giving treatment. The analysis technique did by analyzing the test result data before and after the test. The data were analyzed using the Wilcoxon test because the data were not normally distributed. The Wilcoxon test was conducted to determine the increasing of IAD understanding to the students of PGMI IAIN Bone. The increasing of the understanding IAD for each student could be known by using N-Gain. It calculated N-gain 
between the initial test and the final test using the Hake formula (Meltzer, 2002: 1260), while the formula is:

$$
N-\text { Gain }=\frac{S_{\text {post }}-S_{\text {pres }}}{S_{\text {maks }}-S_{\text {pre }}}
$$

Note: $\mathrm{S}$ post $=$ Score postest, $\mathrm{S}$ pre $=$ Pretest score, $\mathrm{S} \max =$ Ideal maximum score The criteria for obtaining an $\mathrm{N}$-gain score can be selected in the table

Table 1. The Criteria of N-gain

\begin{tabular}{lc}
\hline \multicolumn{1}{c}{ Value } & The Criteria of raising \\
\hline $\mathrm{G} \geq 0,7$ & High \\
\hline $0,3<\mathrm{G}<0,7$ & Medium \\
\hline $\mathrm{G} \leq 0,3$ & Low \\
\hline
\end{tabular}

\section{The Procedure of Research}

Generally, research is the process of finding data. The data of this study was done by the providing of IAD learning to use the scientific approach. Before conducting experiments, the students conducted an initial test or pretest. After the initial test, it continued by conducting experiments using the scientific approach of the learning basic natural science on the material 'Earth and its Layers'.

A scientific approach to learning includes the steps (Yani, 2018: 99)

The first stage was observing. The initial activity was done by IAD learning with the scientific approach to observe, to find and realize the problem. The learning activities undertaken by participants are to listen, to scrutinize, to see, to read books about the material to discuss namely: Earth and its Layers, observing the globe as a miniature of the earth rotating and evolving, when getting irradiated and what its effects on the earth and others related to the earth and its layers .

The second stage was asking. The learning activities could be done was to ask questions about the information did not understand from the observing or the questions to obtain additional information about what they observed. The questions of students asked to begin from factual questions, to lead to suspected questions. The competencies developed the development of the creativity, the curiosity, the ability to formulate questions for the development of critical thinking skills, and the formation of characters who want to learn throughout life.

The third stage of the collection of information. This activity found about questions that arise by finding information on their own via the internet, the reading various sources of information, the observing of the globe, the observing of events, it did certain activities. The competencies developed include: the participants developed attitudes, be honest, be polite, to respect opinions others, to have the ability of communication, to have the ability to gather information in various ways, to develop learning habits. Gathering information / experiments in this study.

The fourth step was to associate. The meaning of associating was processing information that has been obtained. The competencies developed honest, conscientious, disciplined, hardworking, able to apply a thought procedure deductively or inductively to draw conclusions. The step of this research after sufficient information was obtained from the book and after 
conducting experiments to use the globe then the students made associations and the process information and to answer questions that theirselves made.

The fifth stage was to communicate. This stage was the final step of the scientific step. The communication phase was done to develop competence in an attitude of honesty, conscience, tolerance, thinking systematically, it could express opinions of the scientific language. After each group reports their esoteric results to answer their own group questions to regard the material of the Earth and its layers. To find out participants could capture the material, the activity continued with each participant to communicate what had been captured in the learning activity by applying the scientific approach. The communicating of activities made to play by applying everything was a teacher now method, to make a circle while singing and passing the ball to the end of the song and who was holding the ball of the student who tells about his observations. So that the students did not feel tense to convey what they had known but they delivered through 'story telling' and other students listened to their friends told about the earth and its layers, this activity provided the learning experience. The observations obtained through the scientific steps provide an opportunity for students to develop self-competence, to increase self-confidence, to think systematically.

After the steps of the scientific approach activities then proceed with a posttest to find out the increasing of mastery of the knowledge of IAD Earth and its material of the students of PGMI IAIN Bone. Prestest and Posttest results data analyzed by conducting the Wilcoxon test.

\section{Result and discussion}

\subsection{The Data Description of student's knowledge was pretest score before the Saintific approach}

The description of the pretest value data was tabulated and it could be seen in Table 1. It could be seen that there are 6 people $(21 \%)$ who have medium values. The dominance of pretest scores was still low, with 22 people (79\%) to have low scores. Generally, the knowledge of the experimental participants were the students of PGMI IAIN Bone, before learning was still low related to the material of the Earth and its layers. For more details, see the histogram, see Figure 1

Table 2. The Frequency Distribution of Pretest Value was in Basic Natural Science Materials

\begin{tabular}{ccccc}
\hline No & Interval & Frequency & Percentage & Category \\
\hline 1 & $8-10$ & 0 & 0 & High \\
\hline 2 & $4-7$ & 6 & 21 & Medium \\
\hline 3 & $0-3$ & 22 & 79 & low \\
\hline \multicolumn{7}{c}{ Total } & 28 & 100 & \\
\hline
\end{tabular}

Source: Primary Data 


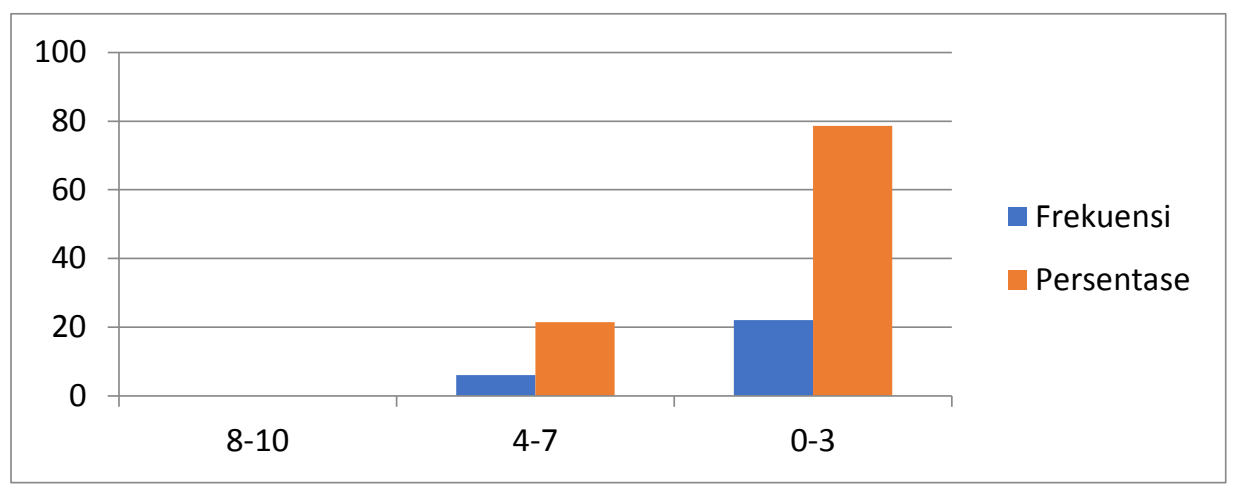

Figure 1. The Pretest Value Histogram of Basic Natural Science Material Understanding

\subsection{The Data Description of the student's knowledge was posttest score after the Saintific approach}

Based on the results of the research conducted to the students of PGMI IAIN Bone, through IAD learning experiments with the scientific approach to the material 'Earth and its Layers', the posttest value obtained as an indicator to see the scientific approach could increase the understanding of the IAD material of the students of PGMI IAIN Bone. The description of the posttest value data could be seen in Table 2 . There were 10 people $(36 \%)$ who have High scores. The dominance of the posttest score was 18 people $(64 \%)$. More details could be seen through the histogram, see Figure 2

Table 3. The Frequency Distribution of Posttest Value was in Basic Natural Sciences material

\begin{tabular}{rcccc}
\hline No & Interval & Frequency & Percentage & Category \\
\hline 1 & $8-10$ & 10 & 36 & High \\
\hline 2 & $4-7$ & 18 & 64 & Medium \\
\hline 3 & $0-3$ & 0 & 0 & Low \\
\hline \multicolumn{2}{c}{ Total } & 28 & 100 & \\
\hline
\end{tabular}

Source: Primary Data

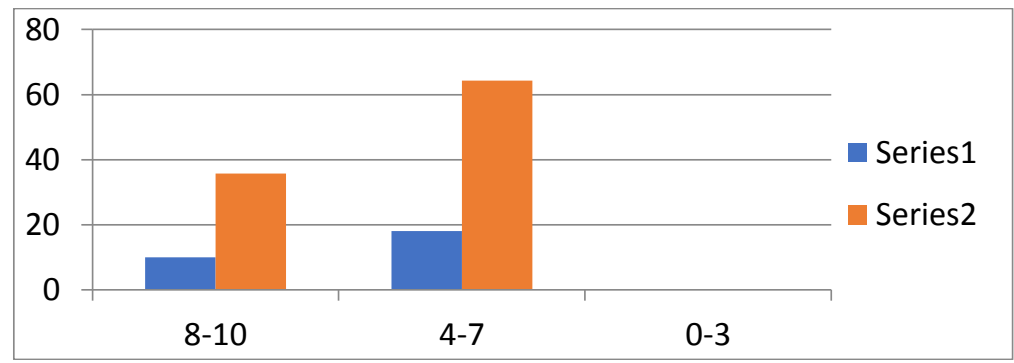

Figure 2. The Histogram of Posttest Value Understanding of IAD Material 


\subsection{Hypothesis testing}

The hypothesis of the research was the temporary to answer the formulation of the problem but in statistics, the hypothesis was interpreted as the statistical statement about the population of the parameters. There were two kinds of hypotheses, namely the null hypothesis and the alternative hypothesis. The null hypothesis showed there was no difference in parameters from one another. The alternative hypothesis was the opposite of the null hypothesis which states the difference between one parameter with another

The statistical hypothesis of this research could be written: Ho: $\mu 1=\mu 2$; Ha: $\mu 1 \neq \mu 2$

Note: Ho: There was no difference of the mastery of IAD material before and after going through the scientific approach to the students of PGMI IAIN Bone.

Ha: There were differences of the mastery of IAD material before and after going through the scientific approach to the students of PGMI IAIN Bone.

Before the hypothesis testing, it was important to analyze the data was normal distribution or abnormal distribution, so the data of this research was done by the Data Normality Test. The Normality Test was one of the fundamental test was done before conducting the data analysis. The Normal data was often the basis of statistical tests. According to Sugiyono (2012: 228) that the using of the parametric statistics such as using t-tests to require the data of each variable would be analyzed, it must be distributed normally. Therefore, before the hypothesis testing, the normality test was done first.

Normality test was used to determine the population data was normal distribution or not. If the normality test used the parametric method, then the analysis requirements must be met, ie the data came from normal distribution. The data declared normal if the significance was greater than $5 \%$ or $\alpha=0.05$ with the test criteria was; If the probability (Sig.) $>0.05$, then Ho accepted and concluded that the residual value (error) spreaded normally. If the Probability (Sig.) $<0.05$ then Ho rejected and concluded that the residual value (error) spreaded abnormally.

Based on the results of the normality test used the parametric method, it could be seen that Sig was 0,000 , this was $\mathrm{Sig}<0.05$, this condition indicated the value was abnormal distribution. So $t$ test could be done. The alternative could be taken to do the hypothesis test to use the Wilcoxon Test. The Wilcoxon test used to analyze the paired observations of two data whether different or not. It signed Rank test to use only for interval or ratio type data, but the data did not follow the normal distribution. Based on the results of the analysis of this research data turned out that the data was abnormal distribution, therefore the Wilcoxon test was performed for the hypothesis testing.

Based on the Wilcoxon test results could be seen Asymp.Sig. (2 tiled) had the value of 0,000 . The basic of the decision for the Wilcoxon test that if the value of Asymp.Sig. (2 tiled) $<0.05$ then the alternative hypothesis (Ha) accepted, but if the Asymp. Sign value $>0.05$ then the alternative hypothesis (Ha) rejected. Based on the calculation results of this study used SPSS 2.0, the Asymp value obtained. Sign (2 tiled) of 0,000 meant the alternative hypothesis (Ha) received which reads: there were differences the mastery of Basic Natural Science material to use the scientific approach of the students of PGMI IAIN Bone. This meant that there was the increasing of the mastery of IAD material by using the scientific approach of IAIN Bone students. To see the improvement of each individual, the N-Gain formula was used. After it saw by individuals, it could be said that it has been the increasing of the basic natural science knowledge after the application of the scientific approach.

In addition doing the Wilcoxon test followed by the N-Gain test to find out the increasing of individual respondents. The results of experiments was conducted to the students of PGMI in the learning basic natural science (IAD) showed that there was the increasing of the mastery 
of IAD material in PGMI IAIN Bone students. It could be seen from the results of calculations to use the N-Gain formula. Based on the results of the final count, it appeared the average score of the participants was 2.93 and after the treatment was obtained 7.43. with the average $\mathrm{N}$-gain value of 0.63 this result meant the knowledge before learning and after learning by using the scientific approach was greater and there are the increasing.

\section{Discussion}

The scientific approach or aproach of the learning was something the discussion material or the attention of educators lately. The background of the importance of this materia was the educational products had not the produced graduates who could to think critically on par with the abilities of other nation's children. The Educators need to strengthen their ability to facilitate the students to be trained to think logically, systematically, and scientifically. This challenge required the improving of the skills of educators implemented the learning to use the scientific approach. The scenarios stimulated the skills of educators to apply this strategy in Indonesia had gone through a long history, but until now this good hope has not yet been realized (Musfiqon, 2015: 49).

The Development of the knowledge realm, attitudes and psychomotor in the world of education needed to get the attention of all stakeholders. (Musfiqon, et al: 2000: 13) said that the scientific approach was a golden bridge of the development and the development of attitudes (affective domain), skills (psychomotor domain), and knowledge (cognitive domain) of students. Through this approach, the students expected to be able to answer their curiosity through the systematic processes as well as the scientific steps. The series of the scientific learning processed the students to find the meaning of learning that could help the students to optimize cognition, affection and psychomotor. The scientists also proceed as the operationalization of this approach, namely by optimizing inductive and deductive reasoning to find out about something. If this practice applied in schools, it would form the continuous scientific custom.

The using of the scientific approach based on Minister of Education and Culture Regulation No. 81 A of 2013, which states that the learning process consist of five main learning experience activities, namely: observing, asking questions, gathering information / experiments, associating / processing information, and communicating (Permendikbud Appendix IV, 2013: 6). The learning process of the ministerial regulation was the learning step with the scientific approach, which it was done at all levels of the education unit to include the madrasah ibtidaiyah. The implementation of the scientific approach in the learning process in madrasah / schools must begin from the improvement of his teacher as the spearhead of learning. The teacher training institutions were the starting point for reforming teachers, so it was important to form pedagogical, professional, social and personality competencies of the prospective teachers since in the education process on campus by strengthening knowledge, attitudes and skills adequately. The implementation of the 2013 revised curriculum required the readiness of teacher because it had an impact of the teacher activities in learning. The teachers had the extensive knowledge and the insight could not lead the students to learn knowledge by memorization but by constructing their own knowledge through the scientific approach that includes: observing, asking, reasoning, and communicating what they had gained after receiving the subject matter.

The knowledge was the result of the human sensing, or the result of the knowing someone about the object through the sense that they had automatically at the time of sensing, so the knowledge was influenced strongly by the intensity of attention and the perception of 
the object. Most of one's knowledge obtained through the sense of hearing, and the sense of sight (Notoatmodjo, 2011: 27). Knowledge arised from the observation of the sense of the surrounding phenomena.

The knowledge formed after a person to make observations through his senses against various phenomena in his environment, then processed the various experiences gained in cognitive into the information arranged regularly and meaningfully, and it was stored in memory, and it could be dug up if needed. Furthermore Suriasumantri (2010: 104) stated the knowledge was all people to know about certain objects essentially. This limit implied that the scope of the knowledge was very broad.

Based on the result of data analysis of this study showed that there were 28 subjects observed the average value of the pretest before it was given the material of the Earth and its layers (preliminary knowledge) was 2.93. It was different when after experimenting with the application of the synthetic approach then the increased average value. The results of the data analyzed of the 28 subjects observed to show that the average posttest value after it was given the material of the Earth and its layers (final knowledge) was 7.43. This showed the increasing when seeing the final grades of the students of PGMI in plain view. As the scientific work, every quantitative research result were analyzed statistically.

Based on the hypothesis testing used the Wilcoxon test, it could be concluded that there was the increasing of the mastery of IAD with the material of the Earth and the layers had been experimented with the scientific approach. The Wilcoxon test result showed an Asymp value. Sign. (2-tiled) $=0,000$, this showed the alternative hypothesis (Ha) accepted, that there were differences of the mastery of IAD material after being treated with the scientific approach. The same thing obtained through calculations by using the N-Gain formula, with an average $\mathrm{N}$-gain value of 0.63 , this meant that the student knowledge had increased after the learning by using the scientific approach. The result showed that there was the increasing of the student knowledge in the learning Basic Natural Sciences by using the scientific approach. The illustrate of this treatment was an activity that could make the change of the increasing and the mastery of IAD material. the scientific approach could enhance knowledge because the students builded their knowledge through the process. There was the change from the original lack of knowledge about the material of the earth and its layers to know.

The scientific approach was an approach that was suitable applied in the $21^{\text {st }}$ century, the digital era and the industrial revolution 4.0 because the students builded their knowledge based on the gained experience through the learning process. According to Piaget in his book Hergenhahn was the optimal education required the challenging experience for participants. Furthermore Piaget stated that a child born has the sensomotor scheme to provide the framework at the beginning of interaction with their environment and it rise the experience as a result of the assimilation. Through interaction with the environment, cognitive structure changed to occur and to experiencethat it would develop in the sustainable manner (Hergenhahn, 2010: 325). The positive approach was an approach to provide the process skills to challenge the students to build their own knowledge based on the scientific methods. The scientific approach could improve one's knowledge, attitudes and behavior because the students got knowledge and experience from their own activities.

This matter was in line with several studies to publish in journals such as Ardaya's research which stated the application of the scientific approach of the learning could improve the students' understanding of the science material (Ardaya, 2016). Erni et al's research stated that the problem-solving ability of the students whose the learning applied the scientific approach was higher than the problem-solving abilities of the students who appling the contextual learning (Erny et al, 2017). Furthermore Aulia et al concluded that the learning by 
using the scientific approach was effective in the increasing students' conceptual understanding and the scientific attitudes on mixed separation material (Aulia et al., 2017). Based on the results of this research and the result of the previous studies, they said that the scientific approach was very recommended for using at all levels of the education unit to include in tertiary institutions as the candidate of teacher. Through the scientific approach, PGMI IAIN Bone students expected to be able to become teachers who have the adequate competence in the future. The teacher of the industrial revolution era 4.0. and the digital age. The using of the scientific approach of the learning required the support of all stakeholders. The teachers could not stand alone without the support of the principal / madrasah, other the supporting of facilities and the infrastructure.

\section{Conclusions}

The Basic Natural Science Learning (IAD) by using the scientific approach could improve the mastery of the material of the Earth and its Layers in the students of Madrasah Ibtidaiyah Teacher Education (PGMI) Bone Islamic State Institute (IAIN). Based on the Wilcoxon test results could be seen that Asymp.Sig. (2 tiled) had a value of 0,000. Basic the decision for the Wilcoxon test that if the value of Asymp.Sig. (2 tiled) $<0.05$ then the alternative hypothesis (Ha) accepted. Based on the calculation results of this study, the Asymp value obtained. Sign ( 2 tiled) of 0,000 meant the alternative hypothesis (Ha) accepted. This scientific approach could improve the mastery of Basic Natural Sciences material of the students of PGMI IAIN Bone.

\section{Acknowledgement}

Thank you to Hj. Falah as my mother and H. Nurdin (deceased) as my father who have brought up and educated. Thank you to M. Radhi, S.E as my husband and M. Naufal as my son. Thank you to the institute of Islamic State of Bone, who funded this research through the 2018 BOPTN.

\section{Reference}

[1] Daryanto. (2014) Pembelajaran Tematik, Terpadu, Terintegrasi (Kurikulum 2013). Jogjakarta: Gava Media.

[2] Dendi Ahmad Ardaya. (2016). Penerapan Pendekatan Saintifik Untuk Meningkatkan Pemahaman Konsep Materi IPA Siswa Sekolah Dasar Program Studi PGSD Departemen Pedagogik Fakultas Ilmu pendidikan Universitas Pendidikan Indonesia. Jurnal Pendidikan Guru Sekolah Dasar, Vol. 1 No. 1, Desember 2016, hlm. 72-83

[3] Erny, Saleh Haji, Wahyu Widada. (2017). Pengaruh Pendekatan Saintifik Pada Pembelajaran Matematika Terhadap Kemampuan Pemecahan Masalah Dan Kemampuan Berpikir Tingkat Tinggi Siswa Kelas X IPA SMA Negeri 1 Kepahiang Jurnal Pendidikan Matematika Raflesia Vol. 2 No. 1 Tahun 2017

[4] Hergenhahn, B.R. \& Olson, M. (2010). Theories of Learning (Teori Belajar). Kencana Prenada Media Group.

[5] Marzuki. (2015). Pendidikan Karakter Islam. Ed. I, Cet. I; Jakarta: Amzah, 2015.

[6] Mulyasa. (2018). Implementasi Kurikulum 2013 Revisi. Jakarta: Bumi Aksara.

[7] Musfiqon dan Nurdyansyah. (2015). Pendekatan Pembelajaran Saintifik. Sidoarjo: Nizamia Learning Centre, 2005.

[8] Nadya Putri Aulia*, Noor Fadiawati, Lisa Tania. (2017). Efektivitas Pendekatan Saintifik dalam Meningkatkan Pemahaman Konseptual pada Materi Pemisahan Campuran . 
FKIP Universitas Lampung, Jurnal Pendidikan dan Pembelajaran Kimia, Vol. 6, No.1 Edisi April 2017, 130-144

[9] Republic of Indonesia. Law No. 20 Year 2003 on National Education System.

[10] Tawil,M \& Liliasari. (2010). Keterampilan-keterampilan Sains dan Imlementasinya dalam Pembelajaran IPA. Makassar : Badan Penerbit UNM.

[11] Yasin Maskoeri. (2010). Ilmu Alamiah Dasar. Jakarta: Radjagrafindo Persada.

[12] Yani, Ahmad \& Ruhimat, Mamat. (2018). Teori dan Implementasi Pembelajaran Saintifik Kurikulum 2013. Bandung: Refika Aditama. 